\title{
NEW DATA ON Cryptonella truyolsi GARCÍA-ALCALDE, 1999, CRYPTONELLID (TEREBRATULIDINA) OF THE CANTABRIAN MOUNTAINS (N SPAIN)
}

\author{
Jenaro L. GARCÍA-ALCALDE \\ Departamento de Geología (Área de Paleontología), Universidad de Oviedo. \\ C/Jesús Arias de Velasco s/n, E-33005 Oviedo (Spain). \\ jalcalde@geol.uniovi.es.
}

\begin{abstract}
García-Alcalde, J. L. 2003. New data on Cryptonella truyolsi García-Alcalde, 1999, cryptonellid (Terebratulidina) of the Cantabrian Mountains (N Spain). [Nuevos datos sobre Cryptonella truyolsi García-Alcalde, 1999, cryptonélido (Terebratulidina) de la Cordillera Cantábrica (Norte de España).] Revista Española de Paleontología, 18 (2), 185-188. ISSN 0213-6937.
\end{abstract}

\begin{abstract}
A new population of Cryptonella truyolsi García-Alcalde, 1999 has been found in Caldas de Luna (province of León, Spain), La Vid Group, Coladilla Formation, level M-CAL-15 (upper part), upper Emsian. Most of morphological characters of the new specimens closely agree with those of the original Cryptonella truyolsi collections. However, serial sections made on a specimen of the new population show an anteriorly open cryptonelliform brachial loop that it is wider, and slightly shorter than that of the original material; furthermore, the descending and ascending branches are only fused along the anterior third of the loop, and the transverse band is narrower, and it is folded at its middle part. The diagnosis of Cryptonella truyolsi is consequently emended.
\end{abstract}

Keywords: Terebratulida Cryptonelloidea, Lower Devonian, Cantabrian Mountains, N Spain, brachial loop.

\section{RESUMEN}

Se ha descubierto una nueva población de Cryptonella truyolsi García-Alcalde, 1999 en Caldas de Luna (provincia de León, España) en el Grupo La Vid, Formación Coladilla, nivel M-CAL-15 (parte superior), del Emsiense superior. La mayor parte de los caracteres mostrados por los individuos de la nueva colección concuerdan con los originales de la especie. Sin embargo, los cortes seriados realizados sobre uno de los nuevos ejemplares mostraba un braquidio criptoneliforme abierto anteriormente, más ancho y débilmente más corto que el apreciado en el material original; además, la parte fundida de las ramas descendentes y ascendentes es menos extensa y la banda transversal más estrecha y plegada en su parte media. Estas diferencias permiten proponer una diagnosis ligeramente enmendada para la especie.

Palabras clave: Terebratulida Cryptonelloidea, Devónico Inferior, Cordillera Cantábrica, N de España, braquidio.

García-Alcalde (1999) described a Lower Devonian terebratulid brachiopod fauna mainly coming from Colle (Sabero, province of León, N Spain). In this paper, the author erected a new species, Cryptonella truyolsi (Cryptonelloidea, Cryptonellinae) honouring the retiring Professor Jaime Truyols of the Department of Geology, University of Oviedo (Spain).

The description of Cryptonella truyolsi was based on 61 variably preserved specimens, 31 of them coming from the type locality, Colle, and the rest from different Asturo-
Leonian localities. All the original material was housed at the Museum of the Department of Geology of Oviedo (DGO).

New material of the species has recently been found in Caldas de Luna (province of León, N Spain) (Fig. 1), in the uppermost part of La Vid Group, and probably corresponds to the Polygnathus serotinus conodont Biozone. The specimen DPO 126507, a rather big specimen, is figured herein in figure 2a-2e (as well as the Holotype of the species DPO 33974, re-figured for comparison purposes, figure 2f-2i). Furthermore, the specimen DPO 126520 was 


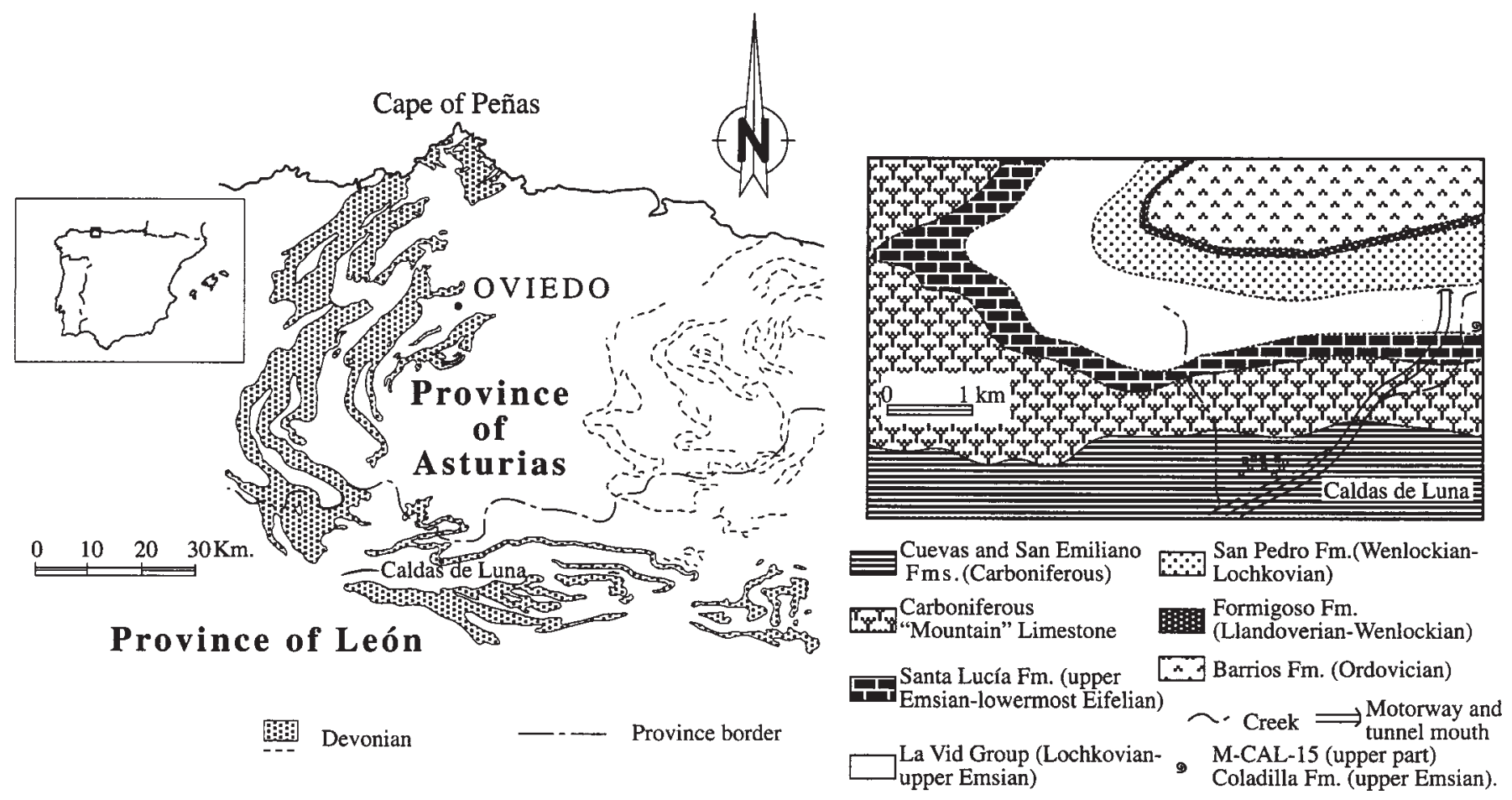

Figure 1. Geographical and geological situation of the new Cryptonella truyolsi material.

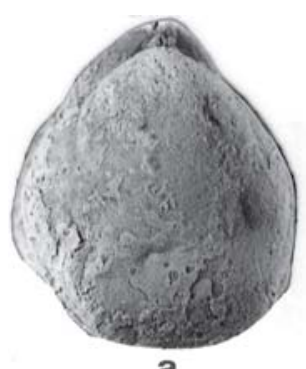

a

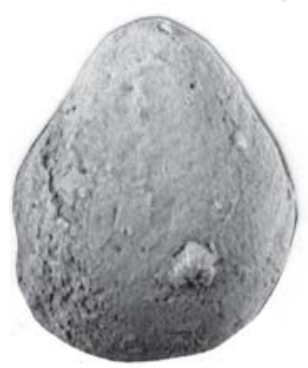

b

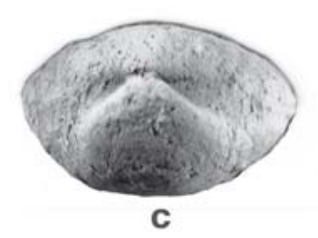

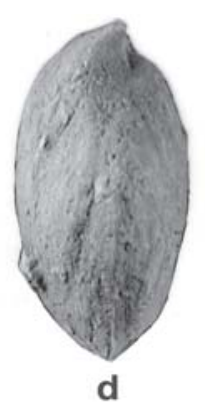
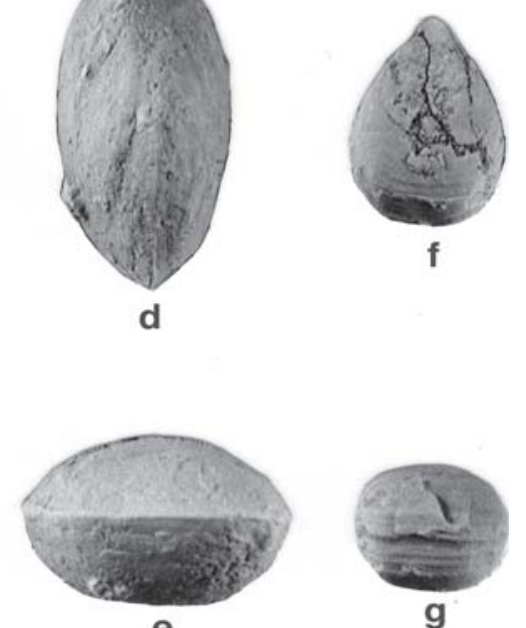

$\mathbf{e}$

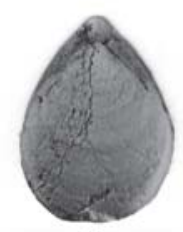

h
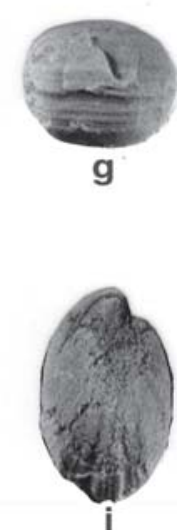

sectioned to show the internal structures (Fig. 3). The new C. truyolsi collection is also housed at the DGO Museum.

The external morphology of the new material closely agrees with the original one $C$. truyolsi, thus the statistical signification level of both the w/L (width/length) and $\mathrm{t} / \mathrm{L}$ (thickness/length) parameters is reinforced (Fig. 4). However, the cryptonelliform brachidium, as observed in the new sectioned specimen, is slightly different (compare Fig. 5 , a and b), being largely open anteriorly, wider (ca. 1/2 of the valve width), relatively shorter, with descending and ascending branches only fused along the anterior third of the loop, and with a narrower, medially folded transverse band. In addition, the loop spines are more numerous than in the original material and are variably oriented both anterolaterally and anteromedially. Because this variability is not greater than the revealed on brachial loops of Recent Terebratulidina species (i.e. Liothyrella species, Lee et al., 2001), it is here considered as intraspecifique.

Other internal characters as the cardinal plate, inner and outer socket ridges, and dorsal foramen, in the dorsal valve, and the pedicle foramen, deltidium, and dental plates, in the ventral valve, are closely similar in both the original and the new material (compare García-Alcalde 1999, Fig. 8, and Fig. 3, herein).

Figure 2. Cryptonella truyolsi García-Alcalde, 1999. a-e: DPO 126507: dorsal, ventral, posterior, lateral, and anterior views. Caldas de Luna ( $\mathrm{N}$ of the province of León), La Vid Group, Coladilla Formation, level M-CAL-15 (upper part), upper Emsian. x3. f-i: Holotype DPO 33974 (reproduced herein with license of the Trabajos de Geología editorial board): ventral, anterior, dorsal, and lateral, views. Colle (Sabero, province of León), La Vid Group, Coladilla Formation, level 32, upper Emsian. x3. 


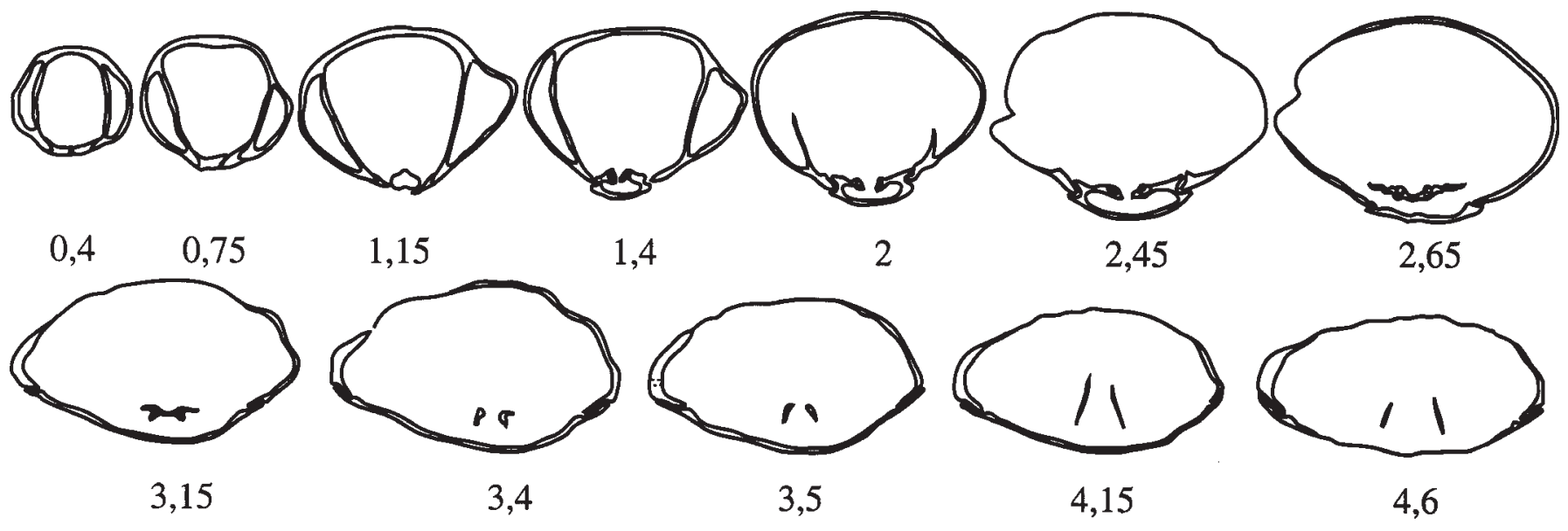

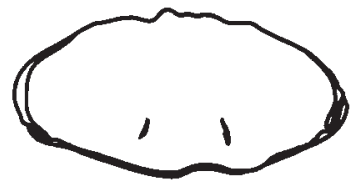

5,4

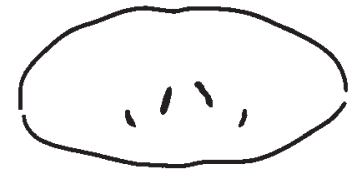

6,25

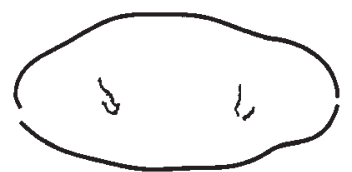

8,3

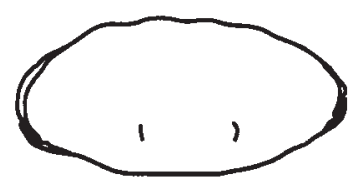

5,1

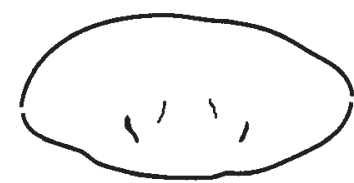

6,9

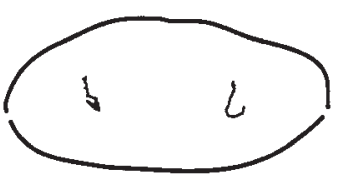

8,7

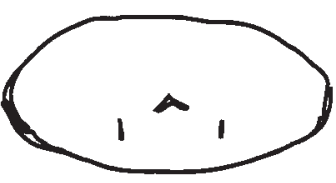

5,6

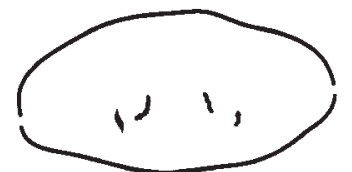

7,1

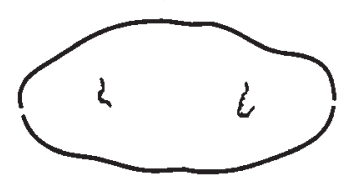

8,9

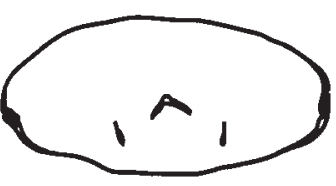

5,75

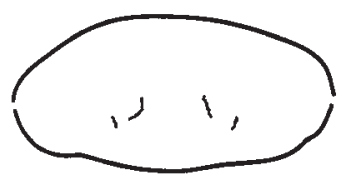

7,5

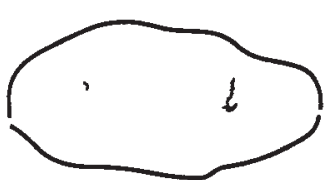

9,3

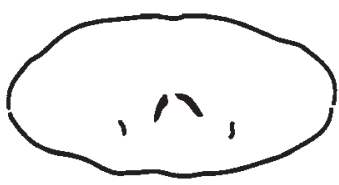

6

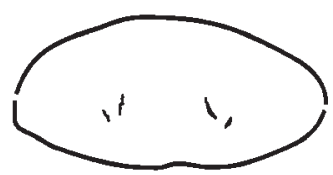

7,7

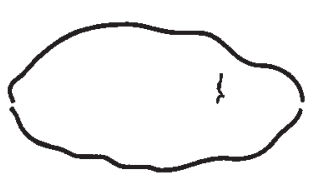

9,6

$\quad 5 \mathrm{~mm}$

Figure 3. Cryptonella truyolsi. Serial sections of the specimen DPO $126520(\mathrm{~L}=14 \mathrm{~mm} ; \mathrm{w}=12 \mathrm{~mm} ; \mathrm{t}=5,9 \mathrm{~mm})$, from Caldas de Luna, uppermost part of La Vid Group, level M-CAL 15 (upper part), upper Emsian.

The new information allows us to propose the following slightly emended diagnosis for Cryptonella truyolsi.

\section{SYSTEMATICS}

CLASS RHYNCHONELLATA Williams et al., 1996 ORDER TEREBRATULIDA Waagen, 1983

SUBORDER TEREBRATULIDINA Waagen, 1883

Superfamily Cryptonelloidea Thomson, 1926

Family Cryptonellidae Thomson, 1926

Subfamily Cryptonellinae Thomson, 1926

Genus Cryptonella Hall, 1861

Type species: Terebratula rectirostrata Hall, 1860.

Cryptonella truyolsi García-Alcalde, 1999

Figs. 2-5 v. 1999 Cryptonella truyolsi n.sp.; García-Alcalde, p. 166, Figs. 7-10, Tab. II.

New material: Eleven variably preserved, mostly decorticated specimens, DPO 126506-126515, and 126520, from the uppermost part of La Vid Group, Coladilla Formation, level M-CAL15 (upper part), upper Emsian.

Emended diagnosis: Small-sized, faintly dorsibiconvex, elongate Cryptonella species with subpentagonal outline and straight to faintly emarginated anterior commissure; suberect to incurved ventral beak; thin, subparallel to dorsally convergent dental plates; fused inner hinge plates forming a posteriorly foraminate, flattened cardinal plate not supported by crural plates; strong crura and crura points supporting a teloform (cryptonelliform) brachial loop more or less open anteriorly, with narrow and flat to medially folded transversal band; descending and ascending loop branches more or less widely fused, with numerous, sharp, projecting spines. 

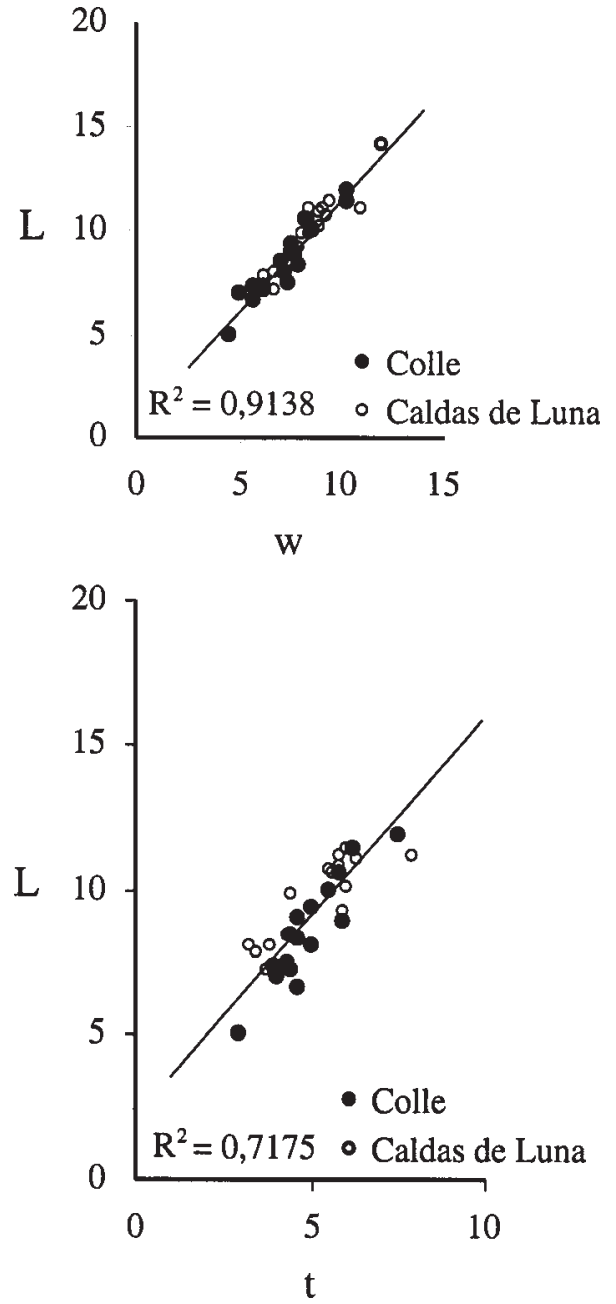

Figure 4. Cryptonella truyolsi. $\mathrm{w} / \mathrm{L}$ and $\mathrm{t} / \mathrm{L}$ (width/length, and thickness/length parameters) of both the original and the new material of the species (in $\mathrm{mm}$ ).

\section{ACKNOWLEDGEMENTS}

I acknowledge with many thanks to the editorial board of the review Trabajos de Geología, Universidad de Oviedo for license the reproduction of the photographies of the $C$. truyolsi Holotype and the brachial loop restoration, both of them included in the original publication (García-Alcalde, 1999). This short note has been completed within the frame of the research projects "Origen de la Paleontología Asturiana. La Fauna del área de Ferroñes", of the University of Oviedo, and PB94/1324 "Eventos geo-biológicos en el Devónico del Macizo Ibérico (España)" (DGICYT).

\section{REFERENCES}

García-Alcalde, J.L. 1999. Terebratúlidos (Braquiópodos) del Emsiense superior de Colle (Sabero, León, N. de España). Trabajos de Geología, 21, 159-176.

Hall, J. 1860. Descriptions on new species of fossils, from the
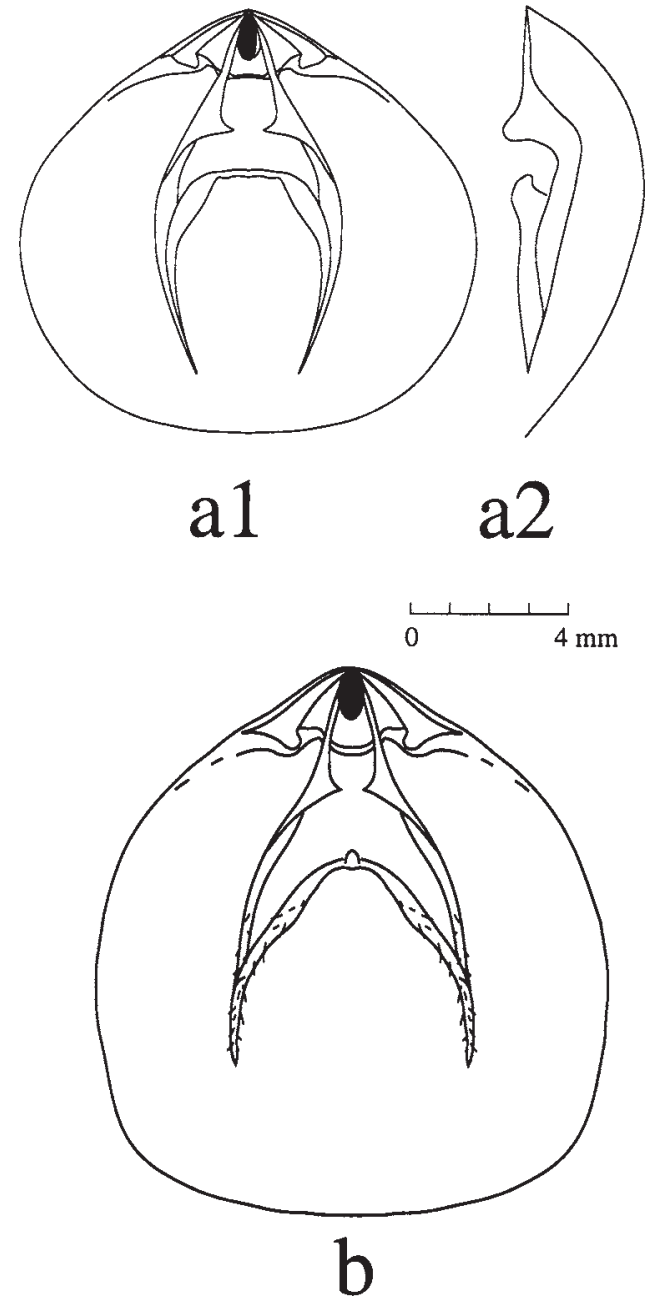

Figure 5a-b. Cryptonella truyolsi. Brachial loop restorations. a: Based on serial sections of the original collection specimens DPO 34052 and 34018 (reproduced herein with the permission of the Trabajos de Geología editorial board). a1-a2: Ventral and lateral views. b: Based on serial sections of the new specimen DPO 126520 , represented on figure 3 . Ventral view.

Hamilton group of western New York, with notices of others from the same horizon in Iowa and Indiana. New York State Cabinet of Natural History, Annual Report, 13, 76-94.

Hall, J. 1861. Descriptions of new species of fossils from the Upper Helderberg, Hamilton, and Chemung groups. New York State Cabinet of Natural History, Annual Report, 14, 99-109.

Lee, D.E., Carlson, S.J., Buening, N. and Samson, C.R. 2001. Variation in the loops of two Recent species of Liothyrella (Brachiopoda; Terebratuloidea) from New Zealand and South Orkney Islands. In: Brachiopods Past and Present (Eds. C.H.C. Brunton, L.R.M. Cocks, and S.L. Long). The Systematics Association Special Volume Series, 63, 56-70.

Manuscrito recibido: 12 de mayo, 2003 Manuscrito aceptado: 17 de julio, 2003 